\title{
LEGAL BASIS FOR INTRODUCING RESTRICTIONS ON HUMAN RIGHTS AND FREEDOMS DURING THE FIRST WAVE OF THE COVID-19 PANDEMIC
}

\author{
Karol Dobrzeniecki* \\ Bogustaw Przywora**
}

\begin{abstract}
In this article, we attempt to present the legal grounds for introducing restrictions on human rights during the COVID-19 pandemic from a comparative legal perspective. We refer to the findings of a research project completed in 2020, trying to synthesize them and confront them with existing theoretical models. We strive to capture general patterns in the legal basis for states' actions in response to global threats such as the COVID-19 pandemic. Comparative legal research contributes to the creation of universal solutions, which, taking into account the specificity of the system, can then be applied in local conditions.
\end{abstract}

Keywords: COVID-19 pandemic, states of emergency, restriction of human rights and freedoms

* Dr. habil. Karol Dobrzeniecki, Associate Professor, Faculty of Law and Administration, Nicolaus Copernicus University in Torun; correspondence address: ul. Bojarskiego 3, 87-100 Toruń, Poland; e-mail: karol.dobrzeniecki@umk.pl; https://orcid.org/0000-0002-6364-9793.

** Dr. habil. Bogusław Przywora, Associate Professor, Faculty of Law and Economy, Jan Długosz University; correspondence address: ul. Zbierskiego 2/4, 42-200 Częstochowa, Poland; e-mail: b.przywora@ujd.edu.pl; https://orcid.org/0000-0002-8809-3971. 


\section{INTRODUCTION}

The World Health Organization declared the outbreak a Public Health Emergency of International Concern in January 2020 and a COVID-19 pandemic in March 2020. Individual states took measures to protect the health and life of the population. In many cases, the actions of public authorities took the form of applying the law in force at the time of the outbreak of a pandemic, provided for in the event of emergencies. Some solutions turned out to be insufficient in the conditions of the existing threat. For this reason, new regulations were created, adapted to the specificity of the current problem. Counteracting the pandemic had an impact on the ability of individuals in terms of exercising their rights and freedoms. The rigors introduced aimed at limiting the spread of the virus had a significant impact on the sphere of collective and individual life. The scale and nature of this impact differed from one legal order to another.

This updated the need to investigate the mechanisms which countries used to combat the pandemic and to assess their impact on fundamental legal goods. In response to the social demand, which was reflected in a lively public debate and protests against "covid" dictates and bans, a research project was undertaken under the title: "Restrictions on civil rights and freedoms during the Covid-19 pandemic. Selected countries" financed by the Institute of Justice. The project analysed solutions operating in the period from March to September 2020 in the following jurisdictions:

1) European countries: the Republic of Austria, the Kingdom of Belgium, the Republic of Belarus, the Czech Republic, the Kingdom of Denmark, the Republic of France, the Kingdom of Spain, the Kingdom of the Netherlands, the Federal Republic of Germany, the Kingdom of Sweden, Ukraine, Hungary, the Kingdom of Great Britain and Northern Ireland, and the Republic of Italy.

2) non-European: Federative Republic of Brazil, People's Republic of China, State of Israel, Canada, United States of Mexico, Republic of Peru, and the United States of America. 
Studies devoted to the legal situation of an individual in the countries indicated were collected in a multi-author monograph published under our editors at the end of $2020^{1}$.

\section{LEGAL MECHANISMS USED IN EMERGENCY SITUATIONS}

2.1. Each of the countries affected by the pandemic tried to adapt the resources at their disposal to the current level of threat, taking into account the conditions resulting from their own constitutional system, cultural considerations, local traditions, the size of the territory, population or population density. The states acted in various regimes - ordinary or extraordinary.

2.1.1. In some countries states of emergency were declared in 2020. In the course of their duration, public authorities were granted special powers, which usually resulted in imposing qualified restrictions on individual rights.

The declaration of a state of emergency does not always mean the same. Its effects differ from jurisdiction to jurisdiction. Most often, it is the basic laws which regulate the procedure for introducing extraordinary measures and their types, as well as the rules of operation of public authorities and the permissible scope of restrictions on the rights of an individual. These issues may also be specified in lower-level normative acts. In both instances law defines the systemic mechanism of the "state of emergency". It is made up of a set of related and coordinated legal norms indicating the purpose of the introduction of a state of emergency, the premises and the mode in which it may be proclaimed and then lifted. There are designated authorities authorized to initiate this state and the manner of their cooperation, the procedure for its declaration, extension and abolition, and sometimes also the permissible duration and territorial scope. Under this particular legal regime, different from normal constitutional solutions, the way in which public authorities and non-governmental entities func-

1 Karol Dobrzeniecki and Bogusław Przywora, eds., Ograniczenia praw i wolności obywatelskich w okresie pandemii Covid-19. Wybrane państwa (Warsaw: Wydawnictwo Instytutu Wymiaru Sprawiedliwości, 2021). 
tion, i.e. enterprises, social organizations and citizens themselves, is changing. The type of parliamentary and judicial control over measures taken during the state of emergency and, possibly, the decision to introduce it, is regulated. The law defines how the scope of competence of individual supreme authorities will be modified and what extraordinary measures will be allowed. It also lays down rules of deviation from the standards of "normal" protection of civil rights. It can expand the scope of an individual's duties, modify institutional guarantees for rights and freedoms, change the system of social and economic relations and the way public officials bear responsibility ${ }^{2}$.

2.1.2. The two dominant legal cultures in the West - civil law and common law - have developed different concepts regarding the choice of the body responsible for protecting the interests of society in connection with the introduction of the state of emergency. The former cast mainly the legislature in this role, the latter mainly the courts ${ }^{3}$. The minimum requirement of the law of the state of emergency in a liberal state is its prospectivity, the introduction of a priori and a posteriori control procedures and the temporary nature of emergency solutions ${ }^{4}$. The normatively assumed purpose of their application is to enable the fastest possible return to the normal situation. Generalizing the solutions occurring at the end of the twentieth century, one can assume the existence of several examples of the basic types of the so-called emergency legislation, the most important of which are the emergency rule and legislative empowerment. The first type, i.e. proper emergency regime, is to design a juridical form of emergency (state of siege, state of emergency, state of internal crisis, etc.). The provisions of the constitution or special laws construct this type

2 Alexander Domrin, The limits of Russian democratization. Emergency powers and states of emergency (London-New York: Routledge, 2006), 27; Ergun Özbudun and Mehmet Turhan, "Emergency powers. Report of European Commission for Democracy through Law (Venice Commission)," Science and Technique of Democracy, no. 12 (1995): $11-30$.

Joseph B. Kelly and George A. Pelletier, "Theories of emergency government," South Dakota Law Review XI (1966): 68-69.

4 Nicole Questiaux, "Study of the implications for human rights of recent developments concerning situations known as the states of siege or emergency," UN Doc. E/CN.4/ Sub.2/1982/15, 1982, par. 34/35: 10. 
of state in advance, and then "keep it in reserve" in the event of certain circumstances. The application of such a previously created legal mechanism most often consists in the delegation of specific competences within the organs of the executive power or within the organs of the judiciary, or between these sectors. Legislative empowerment, on the other hand, means empowering the executive to legislate in an emergency by delegating all or part of the powers of the parliament to it. Here too, various nomenclature describes the functionally identical mechanisms of law-making by the executive (orders, decree laws, regulatory laws etc.). The Basic Law defines the procedure by which the transfer of power may take place, the limits of delegated powers, the content, purpose and scope of the regulation, and sometimes also its time limits.

2.1.3. Most modern constitutions entrust the task of protecting the state under threat to the executive power ${ }^{6}$. Its participation in law-making processes is most often increased by adopting various types of acts replacing the actions of the legislature, which, de jure or de facto, cannot fulfil its tasks. The justification for the delegation of parliamentary powers to the government is usually the belief that the government, being aware of the dynamic changes in the crisis situation, can react to them more effectively. The executive makes rules in an accelerated procedure, often of a decision-making nature. Delegation of legislative powers may be limited in time and to specific situations or may have a permanent character in the event of a future crises. The basis for delegation is the statute or the constitution, depending on the constitutional conditions of a given country. It should also be noted that certain types of threats trigger a reaction of public authorities in the form of executive or legislative actions. For example, riots are more likely to be met with the executive's response, and an economic breakdown with legislative activity, sometimes delegated to the executive ${ }^{7}$.

2.1.4. The international law of human rights uses the concept of public emergency which threatens the life of the nation and the existence of

\footnotetext{
5 Questiaux, "Study," 20-22; Özbudun and Turhan, "Emergency powers," 3-11.

6 Clinton L. Rossiter, Constitutional dictatorship. Crisis government in the modern democracies (Princeton, New Jersey: Routledge, 1948), 12.

7 Rossiter, Constitutional dictatorship, 9-10.
} 
which is officially proclaimed. The occurrence of such a case, after meeting additional conditions, entitles the state to avoid certain obligations to protect the rights of an individual ${ }^{8}$.

In the institutional language of the universal system of human rights protection, the term state of emergency means a legally regulated situation in which state power is exercised under a special order and in accordance with an extraordinary procedure, with the fulfilment of substantive and procedural requirements. There are many categories of emergency in national orders, such as: state of exception ${ }^{9}$, state of siege ${ }^{10}$, state of emergency ${ }^{11}$. Some definitions of legal institutions are not the product of positive legislation, but jurisprudence and doctrine, such as the Anglo-Saxon martial law ${ }^{12}$, or the Swiss régime de strictly necessite ${ }^{13}$. For example, in those countries where the French legal tradition in this area has been adopted, different categories of extraordinary measures are distinguished according

8 Compare: art. 4 The International Covenant on Civil and Political Rights of 19 December 1966.; art. 27 The American Convention on Human Rights of 22 November 1969.; art. 15 Convention for the Protection of Human Rights and Fundamental Freedoms of 4 November 1950.; art. 30 European Social Charter of 18 October 1961.

9 See: art. 212-215, Political Constitution of Colombia, in: Gisbert H. Flanz, ed., Constitutions of the countries of the world, v. IV, Release 95-4, trans. Peter B. Heller, Marcia W Coward (New York: Oceana Publications, 1995), 211-214; art. 93, The Constitution of the People's Democratic Republic of Algeria, in: Gisbert H. Flanz, ed., Constitutions of the countries of the world, v. I, Release 2003-6, trans. Gisbert H. Flanz (New York: Oceana Publications, 2003), 18.

10 France (l'état de siège), Portugal (estado de sitio), Argentina (el estado de sitio), Roma-

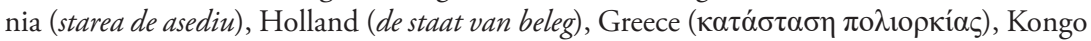
(l'état de siege).

11 Estado de emergencia appears inter alia in the constitution of Peru of 31 December 1993 where it is one los estados de excepción next to estado de sitio, as well as in the constitution of Equador of 11 August 1998. See art. 137, Political constitution of Peru, in: Gisbert. H. Flanz, ed., Constitutions of the countries of the world, v. XIV, Release 95-1, trans. Peter B. Heller (New York: Oceana Publications, 1995), 145; Art. 180, Political constitution of the Republic of Ecuador, in: Gisbert. H. Flanz, Constitutions of the countries of the world, v. VI, Release 99-4, trans. Reka Koerner (New York: Oceana Publications, 1999), 47.

12 The term martial law was established in Great Britain Islands within common law. Its genesis reaches estate monarchy.

13 See: Özbudun and Turhan, "Emergency powers," 5-6. 
to the degree of threat. In the case of the greatest threat (both external and internal), the state of siege is usually introduced, when the threat is less severe, it is a different category, e.g. state of emergency ${ }^{14}$. Various legal solutions may apply depending on the type of threat, its source or the territorial scope of its occurrence. The state of a natural disaster, particularly important during a pandemic, is not a solution commonly used at the constitutional level in modern countries.

2.1.5. In some legal systems, issues relating to natural hazards are not regulated directly in the constitution, but belong to ordinary legislation the field of administrative law ${ }^{15}$. The consequence of this is, among others, a relatively simple possibility of establishing and amending them, and as a result, significant differentiation and variability of legal solutions. Both the terminology and the normative content of the individual institutions used to counter the pandemic differ significantly. The states which did not decide to declare a state of emergency took the position that in the face of a threat, protection of the constitutional values of life and health should be ensured, while maintaining the possibility of an undisturbed functioning of their supreme organs for as long as possible. The attitude defined as constitutional absolutism is characterized by the conviction that "the constitution is equally applicable to wartime and to a period of peace. It should be strictly enforced [...] as its principles remain the same, although the effect of their application in an emergency may differ from that which would have occurred in a normal situation" ${ }^{16}$. In this approach, typical of mature democracies, it was assumed that all future threats were included in the legislator's intention, and the powers necessary to overcome them, assigned to the authorities operating on the basis of the constitution, without the need to resort to extraordinary solutions. Therefore, counteracting all threats, including a pandemic, may, as a rule, take place in the ordinary regime of the functioning of the state by applying the applicable law.

14 Krzysztof Prokop, Modele stanu nadzwyczajnego (Białystok: Temida 2, 2012), 80.

15 Krzysztof Prokop, "Wokół problematyki stanu klęski żywiołowej w konstytucjach państw europejskich," in Studia i szkice z prawa publicznego. Księga dla uczczenia pamięci Profesora Eugeniusza Smoktunowicza, ed. Andrzej Nowakowski (Rzeszów: RS Druk, 2008), 124.

16 Karol Dobrzeniecki, Prawo wobec sytuacji nadzwyczajnej. Między legalizmem a koniecznościa (Toruń: Towarzystwo Naukowe Organizacji i Kierownictwa. Stowarzyszenie Wyższej Użyteczności „Dom Organizatora”, 2018), 189. 
In many cases, the legislation in force at the outbreak of the pandemic was subject to further modifications and supplemented with normative acts aimed at mitigating the economic and social effects of lockdown. In some jurisdictions, soft law solutions (recommendations, plans and procedures) were also important, as they determined technical and organizational issues, in particular the organization of medical and rescue services during an epidemic.

2.1.6. When assessing the response of key countries to the COVID-19 pandemic, it is necessary to take into account not only the state and variability of their legislation, but also the practice of implementing legal standards in the period from the outbreak of the COVID-19 pandemic to September 2020. Restrictions on human rights and freedoms, paying attention to the areas of government interference in this area which are characteristic of a pandemic. These restrictions most often related to personal freedom (compulsory quarantine), the right of movement, freedom of economic activity, freedom of religion (public cult), the right to education or, incidentally, voting rights. At the same time, it should be emphasized that the research took into account various perspectives, such as: the criterion of legality and proportionality (necessity to achieve the public goal), but also rationality, economic effects, appropriate time of introduction and appropriate duration of individual restrictions, the area of their introduction, and the objective scope and subjective.

\section{STATES' RESPONSE TO THE COVID-19 PANDEMIC}

3.1. A state of emergency have been declared in some countries as a remedy for threats caused by the COVID-19 pandemic. In Spain, the Council of Ministers announced (March 14, 2020), by royal decree, a state of alarm (estado de alarma) throughout the country for 15 calendar days to manage a sanitary crisis caused by the COVID-19 pandemic. This status was extended six times with successive royal decrees.

3.2. Likewise, the Government of the Czech Republic announced the state of emergency (nouzový stav) on March 12, 2020 by resolution ${ }^{17}$.

17 Usnesení Vlády České Republiky ze dne 12.03.2020, č. 194; 69/2020 Sb. 
In principle, this state was to last for a period of 30 days, however - due to the development of the pandemic - it was extended twice (initially until April 30, 2020, and under another government resolution, until May $17,2020)$. The basis for adopting relevant resolutions by the Government were Art. 5 and Art. 6 of the Constitutional Act of April 22, 1998 on the security of the Czech Republic ${ }^{18}$.

3.3. In Hungary, on March 11, 2020, the Prime Minister issued a regulation on the declaration of the state of danger (a veszélyhelyzet) in the territory of the state caused by the spread of the COVID-19 pandemic ${ }^{19}$. The legal basis was Art. 53 of the Basic Law. Restrictions were introduced in the scope of, inter alia, movement, border crossing, schools and cultural institutions were closed.

3.4. In France, the parliament adopted the state of emergency law on March 23, 2020 ${ }^{20}$, thus, it gave the government extensive authorization to take measures to counteract the pandemic situation (especially in terms of limiting constitutional freedoms and rights of the individual). The decrees [ordinances] issued by the Prime Minister after the entry into force of this regulation should therefore be considered as consistent with the principle of legalism.

3.5. In Germany, no state of emergency was introduced throughout the country on the basis of Art. 91 Grundgesetz. However, disaster situations (Katastrophenfall) have been introduced in Bavaria and the city of Halle in Saxony-Anhalt.

3.6. In the United States of America, the US government did not take extensive legal action in the first phase of the pandemic. However, on January 31, 2020, The Secretary of Health and Human Services announced a public health emergency under Art. 319 of The Public Health Service $\mathrm{Act}^{21}$. It was not until March 13, 2020 that the US President issued

18 Ústavní zákon ze dne 22.04.1998 o bezpečnosti České republiky, Zák. č. 110/1998 Sb.

19 Regulatiion of the Government of Hungary number 40/2020 of 11 March concerning announcement of the state of threat, A Kormány 40/2020. (III. 11.) Korm. rendelete veszélyhelyzet kihirdetéséröl, „Magyar Közlöny” 2020, no. 39.

20 Loi n 2020-290 du 23 mars 2020 d'urgence pour faire faceàl'épidémie de COVID-19, https://www.legifrance.gouv.fr/affich Texte.do?cidTexte=JORFTEXT0000417463138categorieLien=id, accessed March 10, 2021.

2142 U.S.C. 247 d. 
Proclamation on Declaring a National Emergency Concerning the Novel Coronavirus Disease COVID-19 Outbreak ${ }^{22}$. The solutions adopted in individual states were important for assessing the scope of interference with civil liberties and rights. For example, in California - which as of September 28, 2020 had the highest number of confirmed cases in the United States and the highest number of confirmed cases per capita - the governor announced a state of emergency. However, under the provisions of the Texas Government $\mathrm{Code}^{23}$ the governor of Texas in a declaration issued on March 13, 2020, announced a state of disaster ${ }^{24}$. This declaration was renewed through a series of subsequent proclamations. The Commissioner of Public Health in Texas issued a Declaration of a public health disaster in the state of Texas. In turn, on March 7, 2020, the governor of the state of New York on the basis of the authorization given to him by the Constitution and the law of the State of New York (section 29- $\mathrm{A}^{25}$ ) issued implementing regulation No. $202^{26}$, in which he announced a state-wide disaster emergency.

3.7. Diversification of solutions in individual territorial units also took place in Canada. The basis for taking actions were public health and safety acts and civils emergency measures in each province. The consequence of the announcement of an emergency of public health was the extension of the powers of the person managing the Ministry of Health. The announcement of a state of emergency resulted in the provision of powers to the provincial or territorial government not only in the field of health, but also in other matters (fires, explosions, floods). The government was granted additional powers to take appropriate anti-crisis measures (e.g. the possi-

22 Original text available at the address: https:/www.whitehouse.gov/presidential-actions/proclamation-declaring-national-emergency-concerning-novel-coronavirus-disease-covid-19-outbreak/, accessed March 10, 2021.

23 Section 418.012 of the Texas Government Code.

24 Original text available at the address: https:/gov.texas.gov/uploads/files/press/ DISASTER_covid19_disaster_proclamation_IMAGE_03-13-2020.pdf, accessed March 10, 2021.

25 Site of the New York Senate, https:/www.nysenate.gov/legislation/laws/EXC/29-A, accessed March 10, 2021.

26 Text of the act, https://www.governor.ny.gov/sites/governor.ny.gov/files/atoms/ files/EO_202.pdf, accessed March 10, 2021. 
bility of restricting the movement of citizens) ${ }^{27}$. For example, the province of Alberta announced local emergency states for Calgary and Red Deer on March 15, 202028. In contrast, in the province of British Columbia, an emergency of public health was introduced on March 17, 2020 under the Public Health Act ${ }^{29}$, and the next day - the provincial state of emergency based on the Emergency Program Act of $1996^{30}$. Apart from these initiatives, the activities of the authorities of several districts, such as Vancouver, New Westminster, Delta, Surrey, and Richmond, should be mentioned. They consisted in introducing emergency procedures ${ }^{31}$. A provincial state of emergency was announced in Manitoba on March 20, 2020 (in force for 30 days, then gradually renewed), and on March 30, 2020 an emergency of public health. The basis for the introduction of the first state, chronologically, were the Emergency Measures Act of July 17, 1987, ${ }^{32}$ and for the second state, the Public Health Act of June 13, $2006^{33}$.

3.8. In Peru, counteracting the effects of the pandemic was based on legal solutions tested in similar cases in the past. First of all, it is necessary to point out the issued decrees, on the basis of which the health state of emergency and state of emergency were extended, as well as changes to the existing restrictions were introduced. More than 50 decrees were issued

27 Tyler Dawson, "As the COVID-19 Pandemic Hit, Provinces Declared States of Emergency. Now Many are up for Renewal. Here is a Look at the Current States of Emergency Plans Across the Country," National Post, April 15, 2020, https://nationalpost.com/ news/provincial-states-of-emergencies-were-issued-a-month-ago-most-are-coming-up-forrenewal, accessed March 10, 2020.

28 See: Bill Graveland, "Calgary and Red Deer Implement State of Emergency to Help Fight Spread of Coronavirus," The Globe and Mail, March 16, 2020, https://www. theglobeandmail.com/canada/alberta/article-we-will-get-more-cases-calgary-implementsstate-of-emergency-to, accessed March 10, 2021.

29 Public Health Act assented to May 29, [SBC 2008] CHAPTER 28.

30 Emergency Program Act, B.C. Reg. 477/94; O.C. 1498/94.

31 Stephanie Ip and Scott Brown, "COVID-19 Update for March 19: Here's the Latest on Coronavirus in B.C.," Vancouver Sun, March 20, 2020, https://vancouversun.com/ news/local-news/covid-19-update-for-march-19-heres-the-latest-on-coronavirus-in-b-c, accessed March 10, 2021.

32 The Emergency Measures Act, assented to July 17, 1987, Continuing Consolidation of the Statutes of Manitoba c. E80.

33 The Public Health Act, assented to June 13, 2006, Continuing Consolidation of the Statutes of Manitoba, c P210. 
between March 2020 and September 2020. These acts took various forms depending on the purpose and nature of the norms ${ }^{34}$. There are: legislative decree (Decreto Legislativo), emergency decree (Decreto de Urgencia) and supreme decree (Decreto Supremo). The relevant government administration offices also issued decisions, including ministerial decisions (Resolución Ministerial) and directorial decisions (Resolución Directoral). National state of emergency (Estado de Emergencia Nacional) throughout the country was announced Decreto Supremo of March 15, 2020 for 15 days. Introduced, among others compulsory quarantine. This state of affairs was extended many times and the regulations governing it were modified. In turn, the health state of emergency (Emergencia Sanitaria) was announced on March 11, 2020 on the entire territory of the country on the basis of Decreto Supremo No 008-2020-SA.

3.9. Unlike many countries whose national or federal authorities implemented a policy of limited contact (social isolation), interfering with certain civil liberties and rights, the Brazilian government adopted a different strategy of action. The consequence of the announcement of the state of calamity (estado de calamidade) was the authorization of the federal public administration to make extraordinary expenses not provided for in projected budget. A different approach could be seen at the local level. It boiled down to the fact that a significant number of states and municipalities in Brazil advised the population not to leave their homes, and in several cases, entertainment and sports centres were ordered to close, and public gatherings (especially those related to recreational activities) were banned. For example, in the state of Minas Gerais, a public health emergency (situação de emergência) was announced on March 12, 2020.

3.10. In Mexico, after the outbreak of the pandemic, the president did not use the emergency powers provided for in the constitution, and only on March 27, 2020, he issued a decree declaring emergency actions in areas affected by a threat to public health ${ }^{35}$. Subsequently, the Consejo

34 Dale Beck Furnish, "La jerarquia del ordenamiento juridico peruano," The American Journal of Comparative Law 19, no. 1 (1971): 91-120.

35 Decreto por el que se declaran acciones extraordinarias en las regiones afectadas de todo el territorio nacional en materia de salubridad general para combatir la enfermedad grave de atención prioritaria generada por el virus SARS-CoV-2 (COVID-19), "Diario Oficial de la Federación”, accessed March 10, 2021. 
de Salubridad General introduced a health state of emergency (estado de emergencia sanitaria $)^{36}$. Since May, there has been a change in the policy of the Mexican government. The Ministry of Economy issued the document "Plan for a return to a new normality". It assumed a gradual resumption of production, social and educational activities, which were halted in the earlier phases of the epidemic ${ }^{37}$.

3.11. Israel is a special case in the context of the COVID-19 pandemic. It is a democratic state, but at the same time it has functioned in the conditions of a specific state of emergency since its inception. In response to the new threat, the executive branch used emergency regulations provided for in Israeli law in the event of a state of emergency being introduced. From the beginning of the pandemic, the government was able to spend them without having to obtain special powers. Although the Knesset, as a legislative body, had the possibility to repeal emergency regulations, it turned out to be impossible due to the specific political situation in the initial phase of the pandemic. The centralized system of executive power facilitated the implementation of the measures taken. In a short time, the government was able to issue and enforce regulations, including in the field of quarantine, supervision, and the judiciary.

3.12. In many countries, the main legal instruments used to counteract a pandemic were statutes passed by parliament or lower-order acts. Some national constitutions do not provide for a state of emergency at all, and in some cases the authorities have not decided to announce them despite the formal possibility of doing so. Italy is an example of the former. There is no such institution in the constitution of the republic ${ }^{38}$. It also does not provide for a general suspension or limitation of fundamental rights in

36 Acuerdo por el que se declara como emergencia sanitaria por causa de fuerza mayor, a la epidemia de enfermedad generada por el virus SARS-CoV-2 (COVID-19), "Diario Oficial de la Federación”, 30.03.2020, http://www.dof.gob.mx/nota_detalle.php?codigo=5590745\&fecha=30/03/2020, accessed March 10, 2021.

37 La Nueva Normalidad. Lineamientos Técnicos de Seguridad Sanitaria en el Entorno Laboral, 19.05.2020, https://www.gob.mx/cms/uploads/attachment/file/552762/CPM_ NN_lineamientos_19may20.pdf, accessed March 10, 2021.

38 Constitution of the Republic of Italy of 27 December 1947. 
the event of an internal threat ${ }^{39}$. Article 77 of the Constitution authorizes the Council of Ministers, in case of necessity and urgency, to issue a decree-law (decreti-legge) on its own responsibility, without the need to obtain a prior delegation from parliament. The government has to present the issued regulation to the chambers on the same day, which should adopt the so-called conversion law (legge di conversione) to convert a regulation into a law. This form of law-making is in addition to the authorizations under the National Health Service Act ${ }^{40}$ and Civil Protection Code ${ }^{41}$ was used by the government and territorial administration to issue the regulations by which the pandemic was managed in Italy ${ }^{42}$.

3.13. Another example of counteracting a pandemic (without the use of an emergency institution) is the policy of the People's Republic of China, where cases of COVID-19 infection were first identified in Wuhan, the capital of Hubei Province ${ }^{43}$. The Chinese legal system, thanks to the experience of the SARS-CoV-2 coronavirus epidemic in 2002-2003, was prepared for another pandemic. Due to the legal specificity of this state, the regulations on restrictions on the exercise of freedoms and rights do not appear in constitutional regulations, but at the level of statutes as well as in executive acts. In China, the first level of threat was announced, albeit with a significant delay, on the basis of the Emergency Response Law and its implementing acts. As a consequence, the state authorities were authorized to introduce restrictions on freedoms and

39 See: Marina Albisinni and Licia Giannone, "L'insegnamento del COVID-19 sullo stato di emergenza: non è mai troppo tardi," Questione Giustizia, June 19, 2020, https:// www.questionegiustizia.it/articolo/l-insegnamento-del-COVID-19-sullo-stato-di-emergenza-non-e-mai-troppo-tardi, accessed March 10, 2021.

40 Legge 23 dicembre 1978, n. 833. Instituzione del servizio sanitario nazionale. (GU Serie Generale n. 360 del 28-12-1978 - Suppl. Ordinario).

${ }^{41}$ Decreto legislativo 2 gennaio 2018, n. 1. Codice della protezione civile. GU Serie Generale n. 17 del 22-01-2018.

42 Compare: Monika Urbaniak, "Lex coronavirus. Włoskie prawo w walce z pandemią, Studia Prawa Publicznego 1 (2020): 11, https://repozytorium.amu.edu.pl/bitstream/10593/25720/3/23300-Tekst\%20artyku\%c5\%82u-47978-1-10-20200625.pdf, accessed March 10, 2021.

43 Hengbo Zhu, Li Wei, and Ping Niu, "The novel coronavirus outbreak in Wuhan, China," Global Health Research and Policy 5, no. 1 (2020): 1, https://ghrp.biomedcentral. com/articles/10.1186/s41256-020-00135-6, accessed March 10, 2021. 
rights (in the first place: personal freedom, movement, respect for property, economic freedom, freedom of religion, the right to education). In the second stage of counteracting the COVID-19 pandemic, the central government of China imposed a lockdown in Wuhan. Public transport was suspended, airports, train stations and highways were closed, citizens were banned from entering and leaving Wuhan ${ }^{44}$. Similar rules have been imposed in other Hubei cities, implementing, inter alia, different levels of traffic control.

3.14. There was also no state of emergency in the Kingdom of the Netherlands. At the time of the outbreak of the pandemic, there were regulations in place regulating emergency cases in the field of public health, including in the Public Health Law of 9 October 2008 (Wet publieke gezondheid) ${ }^{45}$. The purpose of this law was to prepare the state for crises related to infectious diseases. The act defined the rules of infectious disease control. This regulation was the main instrument to introduce control measures related to combating and counteracting the COVID-19 pandemic.

3.15. The law of the United Kingdom of Great Britain and Northern Ireland provides provisions relating to the issue of mass infections. Under the Public Health (Control of Disease) Act 1984, the competent minister may, by means of ordinances, make provisions to prevent, protect, control or ensure a response from the public health service to the occurrence or spread of an infection or contamination in England and Wales (whether the risk is external or internal) ${ }^{46}$. This act is the basis for introducing solutions that interfere with civil liberties and rights in connection with counteracting mass infections (e.g. with regard to the organization

44 Message of the authorities of Wuhan available in Chinese at the site: http://jyh.wuhan.gov.cn/pub/whs_70/zwgk/tzgg/202003/t20200316_972434.shtml, accessed March 10, 2021.

45 Staatsblad 2008, 460.

46 An Act to consolidate certain enactments relating to the control of disease and to the establishment and functions of port health authorities, including enactments relating to burial and cremation and to the regulation of common lodging-houses and canal boats, with amendments to give effect to recommendations of the Law Commission, 26 June 1984, UK Public General Acts, 1984 Chapter 22, https://www.legislation.gov.uk/ukpga/1984/22/section/45C, accessed March 10, 2021. 
of mass events or public gatherings, performance of school duties, etc. ${ }^{47}$ ). The Health Protection (Coronavirus Restrictions) Regulations were the basic act determining the scope of exercising civil rights during the COVID-19 pandemic in England ${ }^{48}$. The Regulations were issued on March 26, 2020 and entered into force on the same day. Similar legal solutions have been adopted for Wales, Scotland and Northern Ireland.

3.16. There was no state of emergency in Austria either. The operation of the provisional law-amending ordinances of the Federal President was also not permissible during the pandemic period due to the fact that not all constitutional conditions were met, in particular the condition that the National Council could not assemble in good time or its activity was impossible due to force majeure. As in many other countries, Austria had laws in place before 2020 to combat infectious diseases. The most important act was the Federal Epidemic Law dating back to 1913 (Bundesgesetz über die Verhütung und Bekämpfung übertragbarer Krankheiten $)^{49}$.

This law enumerated diseases subject to the obligation to notify, the occurrence of which entitles the use of extraordinary "preventive measures" (e.g. isolating the sick or suspected of falling ill, disinfection, restrictions in food circulation, events involving a large number of people, closure of educational institutions, emptying the premises, etc.). The first actions in the field of counteracting the COVID-19 pandemic at the federal level were based on this act. On February 28, 2020, the Federal Minister of Social Affairs, Health, Care and Consumer Protection issued an ordinance according to which the preventive measures provided for in the Outbreak Act to restrict the activity of entrepreneurs could also be applied in the case of COVID-19 infection.

3.17. In Ukraine, from March 2020, restrictive regulations limiting freedom and constitutional rights began to be introduced. The President of Ukraine has issued a presidential decree approving the decision of the National Security and Defence Council of Ukraine about immediate

47 Ibidem, sek. 45C 4 (a).

48 Health Protection (Coronavirus Restrictions) (England) Regulations 2020, 26 March 2020, Statutory Instruments, 2020 N. 350, https:/www.legislation.gov.uk/uksi/2020/350/contents/ made, accessed March 10, 2021.

49 Bundesgesetzblatt für die Republik Österreich of 1950, it. 186 as amended. 
measures on ensuring national security in the conditions of the outbreak of sharp respiratory disease of COVID-19. The pandemic was considered a state threatening the interests of the state and its citizens, but it was not decided to announce a state of natural disaster on all or part of the state's territory.

3.18. In the Kingdom of Belgium, the constitution does not provide for a state of emergency, nor does it contain a general limitation clause in the context of counteracting a pandemic. The first emergency measures at the federal level were introduced under the ministerial order of March 13, 2020. a ban on cultural, social, sports and entertainment activities, both in the private and public dimension, and religious ceremonies (les activités des cérémonies religieuses), except for funerals and activities in the circle of relatives and family; suspension of school education, partial restriction of trade on Saturdays and Sundays ${ }^{50}$. Further preventive measures were introduced under the ministerial order of March 23, 2020. Assemblies, all cultural, social, sports and entertainment activities, both in the private and public dimension, were banned (les activités à caractère privé ou public, de nature culturelle, sociale, festive, folklore, sportive et récréative), religious ceremonies (les activités des cérémonies religieuses), organized tours.

On March 27, 2020, the House of Representatives adopted two laws empowering the King to take the necessary measures to prevent the spread of COVID-1951. The power to define administrative, civil and criminal sanctions was granted for a period of three months with the possibility of extending it once for another three months. In addition, a requirement was introduced that provisions issued on the basis of pouvoirs spéciaux were adopted by the entire Council of Ministers (par le Roi, délibéré en Conseil des ministres) and approved by parliament within one year from the date of entry into force. In practice, the Federal Government has been given extensive powers to mitigate the negative effects of a pandemic. Based on

50 Arrêté ministériel du 13 mars 2020 portant des mesures d'urgence pour limiter la propagation du coronavirus COVID-19.

51 Loi du 27 mars 2020 habilitant le Roi à prendre des mesures de lutte contre la propagation du coronavirus, http://www.ejustice.just.fgov.be/eli/loi/2020/03/27/2020040937/ justel; Loi du 27 mars 2020 habilitant le Roi à prendre des mesures de lutte contre la propagation du coronavirus COVID-19 (II), (Moniteur belge, 30 mars 2020), http://www. ejustice.just.fgov.be/eli/loi/2020/03/27/2020040938/justel, accessed February 28, 2021. 
the aforementioned statutory delegation, it was issued, inter alia, royal decree (arrêté royal) of April 6, 2020 authorizing municipal authorities to introduce additional administrative sanctions for violating the provisions of the ordinance of the minister of security and internal affairs of March 23, 2020 concerning, closing stores and introducing an obligation to social distance ${ }^{52}$. The authorities of the Walloon Region, the French Community, the Brussels-Capital Region, the Joint Community Commission of the Brussels-Capital Region (Commission communautaire commune, COCOM), the French Community Commission of the Brussels-Capital Region (Commission communautaire française, COCOF) and the German-speaking Community took advantage of the possibility of transferring special powers to the executive ${ }^{53}$.

3.19. In Denmark, the Parliament (Folketing) approved the government's draft amendment to the law on counteracting epidemics and infectious diseases, commonly known as the "law on epidemics". On the basis of this amendment, which entered into force on March 17, 2020 the government, health and justice ministers and relevant government agencies were given additional regulatory powers.

3.20. In the Kingdom of Sweden, unlike most countries, in the first phase of the pandemic, no restrictive model of restrictions on the freedom and rights of citizens was adopted. The authorities responded by skilfully adjusting the existing legal instruments to combat the new threat. The Swedish legislator practically did not introduce limitations of rights and freedoms at the sub-statutory level. The Swedish basic laws did not provide for the possibility of introducing emergency measures that would enable the authorities (state) to react to a pandemic. The 2010 amendment to the Instrument of Government (Regeringsformen) ${ }^{54}$ created the basis for introducing limitations in the rights and freedoms of citizens in connec-

52 Arrêté royal n ${ }^{\circ} 1$ du 6 avril 2020 portant sur la lutte contre le non-respect des mesures d'urgence pour limiter la propagation du coronavirus COVID-19 par la mise en place de sanctions administratives communales. (Moniteur belge, 7 avril 2020), http://www.ejustice. just.fgov.be/eli/arrete/2020/04/06/2020020733/moniteur, accessed February 28, 2021.

53 Frédéric Bouhon, Andy Jousten, Xavier Miny, and Emmanuel Slautsky, "L'État belge face à la pandémie de Covid-19 : esquisse d'un régime d'exception," Courrier hebdomadaire du CRISP 2446 (2020): 26-33.

54 “The Svensk författningssamling” 2010:1408 Lag om ändring i regeringsformena. 
tion with the threat of "plague" in secondary legislation. In the event that the Parliament of the Kingdom of Sweden could not expeditedly adopt an amendment to the law in the form of adding a specific disease entity to the list of contagious diseases, special powers in this regard were granted to the government. In Sweden, recommendations and guidelines addressed to citizens, entrepreneurs running restaurants, organizing mass events, and manufacturers of medicines and hygiene products were widely used.

3.21. Compared to other countries covered by the study, the Belarusian authorities presented an original approach to the COVID-19 pandemic. In the first months of its duration, the government denied the need to significantly change the regulations or introduce restrictions. Authorities have declared no emergency or virtually no administrative restrictions to protect citizens' health and prevent the spread of COVID-19. A regulation of the Council of Ministers of February 5, 2020 on the organization of preventive actions (О ведении ограничительного мероприятия) $)^{55}$ was issued ordering that people who came to Belarus from countries where cases of infection with COVID-19 have been reported and not self-isolate before the end of the period of self-isolation crossed the state border. The regulation of the Council of Ministers of the Republic of Belarus of April 8, 2020 ${ }^{56}$ imposed self-isolation on people infected with COVID-19 and those who had contact with the infected. Those in self-isolation were not allowed to leave their place of residence or stay, stay in the workplace, study, commercial and gastronomic facilities, sports, entertainment and concert halls, cinemas, railway stations and other places of mass concentration of people. Violation of the requirements of self-isolation established by the regulation entails liability in accordance with legislative acts. Preventive measures were introduced and revoked by a decision of the Council of Ministers of the Republic of Belarus, local executive and administrative bodies at the request of the Deputy Minister of Health - Chief State

55 Постановление Совета Министров Республики Беларусь от 25.03.2020 № 171 «о мерах по предотвращению завоза и распространения инфекиии, вызванной коронавирусом COVID-19”, „Национальный правовой Интернет-портал Республики Беларусь”, 27.03.2020, 5/47931 as amended.

56 Постановление Совета Министров Республики Беларусь от 8 апреля 2020 г. N 208 „о введении ограничительного мероприятия”, „Национальный правовой Интернет-портал Республики Беларусь”, 9.04.2020, 5/47975. 
Sanitary Doctor of the Republic of Belarus, and locally in oblasts, cities and districts at the request of the chief state sanitary doctors of oblasts, cities and districts.

3.22. In the light of the above list, it seems legitimate to conclude that the legal solutions functioning in the analysed countries during the COVID-19 pandemic were determined by the varying degree of preparation of the legal system of a given country to epidemiological challenges. At the first stage of counteracting the COVID-19 pandemic, countries attempted to apply existing regulations to the resulting threat or introduced new statutory or sub-statutory solutions, primarily guided by the criterion of the effectiveness of public authority activities. The adopted political and legal strategy was influenced by experience in combating epidemic threats, as well as by the conditions of internal policy. It is impossible to notice a simple relationship between resorting to emergency solutions, provided for in the constitutions, and effectiveness in counteracting a pandemic.

\section{FINAL CONCLUSIONS}

A number of conclusions can be drawn from the research carried out. Firstly, states tried to adapt their measures to the current degree of threat, taking into account the conditions resulting from their own constitutional system, cultural considerations, as well as local traditions, size of the territory, population or population density. The status of an individual was influenced by the way human rights were codified in the text of the particular constitution at the time of its creation. Older constitutions, such as the Dutch, Norwegian or Danish constitutions, devote less space to freedoms and rights. The constitutions adopted after World War II - under the influence of her experiences - such as the Italian or Spanish ones, regulate this matter in a more comprehensive manner. In federal states (e.g. the USA, Canada, Germany, Belgium), the issues of protection of freedoms and rights are divided between federal regulations and regulations of states, provinces and countries; a similar division applies to the mechanisms conditioning their compliance and protection. 
Second, countries responded in different ways to emergencies related to the pandemic. In some countries, states of emergency were announced in 2020, while in others efforts were made to undertake activities based on applicable statutory regulations. Regardless of the mode, during the pandemic, public authorities were granted special powers, which usually resulted in qualified restrictions on individual rights.

Third, the above synthesis concerns the so-called the first wave of COVID-19 cases. With this in mind, it should be recognized that research on the issue of restrictions on the freedoms and rights of an individual in subsequent phases of the COVID-19 pandemic should be continued, and the final conclusions in this regard may be drawn only after its end. COVID-19 pandemic prevention constitutes an important reference point for future legislative and executive actions. States are forced to react dynamically in order to adapt legal and organizational solutions to new situations and threats in 2021. The functioning of the state and the implementation of its basic tasks when the life and health of citizens is at risk requires special involvement of public institutions within the legal framework enabling its efficient operation ${ }^{57}$.

Fourthly, the epidemic in the analysed countries is a challenge from the point of view of ensuring the uninterrupted functioning of public institutions, as well as the possibility of running a business and guaranteeing individual rights and freedoms. The fundamental question remains: what is the limit of interference with civil rights and freedoms that is possible in the normal course of the functioning of the state and in the case of the introduction of one of the constitutional extraordinary states (as long as it is foreseen and admissible in the light of constitutional provisions).

57 Compare: Robert Tabaszewski, "The permissibility of limiting rights and freedoms in the European and national legal systems due to health protection," Review of European and Comparative Law 42, no. 3 (2020): 51-89, https://doi.org/10.31743/recl.6100. 


\section{REFERENCES}

Albisinni, Marina, and Licia Giannone. "L'insegnamento del COVID-19 sullo stato di emergenza: non è mai troppo tardi." Questione Giustizia, June 19, 2020. https://www.questionegiustizia.it/articolo/l-insegnamento-del-COVID19-sullo-stato-di-emergenza-non-e-mai-troppo-tardi. Accessed March 10, 2021. Bouhon, Frédéric, Andy Jousten, Xavier Miny, and Emmanuel Slautsky. "L’État belge face à la pandémie de Covid-19: esquisse d'un régime d'exception." Courrier hebdomadaire du CRISP 2446 (2020): 1-56.

Ip, Stephanie, and Scott Brown. "COVID-19 Update for March 19: Here's the Latest on Coronavirus in B.C." Vancouver Sun, March 20, 2020. https:// vancouversun.com/news/local-news/covid-19-update-for-march-19-heresthe-latest-on-coronavirus-in-b-c. Accessed March 10, 2021.

Dawson, Tyler. "As the COVID-19 Pandemic Hit, Provinces Declared States of Emergency. Now Many are up for Renewal. Here is a Look at the Current States of Emergency Plans Across the Country." National Post, April 15, 2020. https:// nationalpost.com/news/provincial-states-of-emergencies-were-issued-a-monthago-most-are-coming-up-for-renewal. Accessed March 10, 2020.

Dobrzeniecki, Karol. Prawo wobec sytuacji nadzwyczajnej. Między legalizmem a koniecznością. Toruń: Towarzystwo Naukowe Organizacji i Kierownictwa. Stowarzyszenie Wyższej Użyteczności „Dom Organizatora”, 2018.

Dobrzeniecki, Karol, and Bogusław Przywora, eds. Ograniczenia praw i wolności w okresie pandemii Covid-19. Wybrane państwa. Warsaw: Wydawnictwo Instytutu Wymiaru Sprawiedliwości, 2021.

Domrin, Alexander. The limits of Russian democratization. Emergency powers and states of emergency. London-New York: Routledge, 2006.

Furnish, Dale Beck. "La jerarquia del ordenamiento juridico peruano." The American Journal of Comparative Law 19, no. 1 (1971): 91-120.

Graveland, Bill. "Calgary and Red Deer Implement State of Emergency to Help Fight Spread of Coronavirus." The Globe and Mail, March 16, 2020. https:// www.theglobeandmail.com/canada/alberta/article-we-will-get-more-casescalgary-implements-state-of-emergency-to. Accessed March 10, 2021.

Kelly, Joseph B., and George A. Pelletier. "Theories of emergency government." South Dakota Law Review XI (1966): 42-69.

Hengbo, Zhu, Li Wei, and Ping Niu. "The novel coronavirus outbreak in Wuhan, China." Global Health Research and Policy 5, no. 1 (2020). https://ghrp.biomedcentral.com/articles/10.1186/s41256-020-00135-6. Accessed March 10, 2021. 
Urbaniak, Monika. "Lex coronavirus. Włoskie prawo w walce z pandemią." Studia Prawa Publicznego 1 (2020): 9-26.

Prokop, Krzysztof. Modele stanu nadzwyczajnego. Białystok: Temida 2, 2012.

Prokop, Krzysztof. "Wokół problematyki stanu klęski żywiołowej w konstytucjach państw europejskich.” In Studia i szkice z prawa publicznego. Ksiegga dla uczczenia pamięci Profesora Eugeniusza Smoktunowicza, edited by Andrzej Nowakowski, 124-143. Rzeszów: RS Druk, 2008.

Rossiter, Clinton L. Constitutional dictatorship. Crisis government in the modern democracies. Princeton, New Jersey: Routledge, 1948.

Tabaszewski, Robert. "The permissibility of limiting rights and freedoms in the European and national legal systems due to health protection." Review of European and Comparative Law 42, no. 3 (2020): 51-89. https://doi.org/ $10.31743 /$ recl.6100.

Questiaux, Nicole. "Study of the implications for human rights of recent developments concerning situations known as the states of siege or emergency." $U N$ Doc. E/CN.4/Sub.2/1982/15, 1982, par. 34/35. 
